\title{
Artículos
}

\section{Spatial and Economic Assessment of Butterfly-Based Handicrafts as a Tourism Service Provided by Rural} Populations*

How to cite this article: Jacinto-Padilla, J., Lopez-Collado, J., Garcia-Garcia, C. G., \& Lopez-Collado, C. J. (2021). Spatial and economic assessment of butterfly-based handicrafts as a tourism service provided by rural populations. Cuadernos de Desarrollo Rural, I8. https://doi.org/I0.III44/Ja veriana.cdri8.seab

Jose Lopez-Collado ${ }^{\mathrm{a}}$

Colegio de Postgraduados, México

jlopez@colpos.mx

ORCID: https://orcid.org/0000-0002-8947-2367

Jazmin Jacinto-Padilla

Colegio de Postgraduados, México

ORCID: https://orcid.org/0000-0002-2292-7355

Carlos Gilberto Garcia-Garcia

Colegio de Postgraduados, México

Catalino Jorge Lopez-Collado

Colegio de Postgraduados, México

ORCID: https://orcid.org/0000-0003-3182-6027

DOI: https://doi.org/IO.III44/Javeriana.cdrı8.seab

Received: 25 July 2019 I Accepted: II November 2020 I Published: 25 August 202I

\section{Abstract:}

Butterfly-based handicraft activities are usually performed around or within natural reserves. Using these insects in a sustainable way by rural communities should address multiple factors, goals and conservation constraints. This study ranks tourist zones in Veracruz, México, to create and market butterfly-based handicrafts by applying a multicriteria analysis. We differentiated top zones where a segment of the rural population

\footnotetext{
${ }^{\text {a } C o r r e s p o n d i n g ~ a u t h o r . ~ E-m a i l: ~ j l o p e z @ c o l p o s . m x ~}$
} 
could benefit from this activity. Roads, butterfly diversity, and tourists emerge as key elements while protected areas and transport costs were considered as constraints. The economic value of the butterfly-based handicraft market was estimated as well.

Keywords: economic diversification, entomotourism, market share assessment, wildlife sustainability.

\section{Evaluación espacial y económica de la artesanía basada en mariposas como servicio turístico prestado por poblaciones rurales}

\section{Resumen:}

Las actividades de artesanía basadas en mariposas generalmente se realizan alrededor o dentro de las reservas naturales. El uso de estos insectos de manera sostenible por parte de las comunidades rurales debe abordar múltiples factores, metas y limitaciones de la conservación. Este estudio clasifica las zonas turísticas de Veracruz, México, donde se crean y comercializan artesanías basadas en las mariposas, aplicando un análisis multi-criterios. Diferenciamos las zonas más importantes donde un segmento de la población rural podría beneficiarse de esta actividad. Caminos, diversidad de mariposas y turistas surgen como elementos claves mientras que las áreas protegidas y los costos de transporte fueron considerados como limitaciones. También se estimó el valor económico del mercado de artesanías basadas en las mariposas.

Palabras clave: diversificación económica, entomoturismo, evaluación de la participación en el mercado, sostenibilidad de la vida silvestre.

\section{Introduction}

Tourism is ranked third as an income source for Mexico, and the country is among the top ten destinations for international tourists. It represents near 8.5\% of the Gross Domestic Product and received 32.I million international tourists and contributed to the economy with US \$15.5 billion in 2015 (Sistema Nacional de la Información Estadística del Sector Turismo de México [DATATUR], 2016; Organization for Economic Cooperation and Development [OECD], 2017). The main tourist attractions are related to its richness in natural resources, historic and cultural heritage, and distinctive regional cuisine, along with festivals and custom celebrations (CamarenaGómez et al., 20I4). In México, the value of entomotourism activities is between US \$44.2 million to US $\$ 88.5$ million per year for the monarch butterfly only, while tourists spend near US \$913.6 million in souvenirs (JacintoPadilla et al., 2017). The state of Veracruz is an important tourist attraction due to the diverse services it provides to the national and international visitors; therefore, it is ranked fifth nationwide (Secretaría de Turismo [Sectur], 2013). Main natural attractions include beaches, rivers, lagoons, thermal springs, mountains, and sand dunes. Other attractions are archaeological sites, colonial towns, museums, local festivals and carnivals. The diversity of services allows having visitants during the whole year and not only on Easter or vacation periods (Secretaría de Turismo y Cultura [Secturv], 2018).

On the other hand, the state of Veracruz is ranked third in biodiversity, and is rich in butterfly species with a potential to make and trade handicrafts, aimed to the visitors (Lopez-Collado et al., 20I6). Species like Morpho belenor Cramer, Danaus gilippus Cramer and Heliconius erato L., are currently traded in different ways (Boppré \& VaneWright, 20I2; Mulanovich, 2007). Some countries in Central and South America already benefit from processing insects into souvenirs or handicrafts to generate revenues in rural communities (Fagua et al., 2002; Mulanovich, 2007). Common and widespread butterfly species can be processed to create handicrafts such as earrings, key chains, 
framed dry-specimens, necklaces, lamps, among others (Cruz-Salas, 20II). The activities of collecting butterflies, creating and selling butterfly-based handicrafts and souvenirs promote recognizing the importance of biological diversity by the local population within their surrounding geographic area (Saragos-Méndez \& Patriganni, 20I2). Souvenirs also help to spread cultural values, historic and biological wealth as a part of the essence of people groups (Buenaño-Allauca et al., 20I7; De Mello \& Ciliane-Ceretta, 2015). Handicrafts are a form of visual communication where the tourist adds a sentimental value to the acquired craft, recreating in his/her memory images of the experiences lived in the place visited. Therefore, a craft represents the bio-cultural heritage of a specific region and becomes a source of identity (López-Reyes \& Gómez-Hinojosa, 2016). Thus, the creation and sale of butterfly-based handicrafts, not only serve the purpose of obtaining economic income for the people who can dedicate themselves to this activity, but also as a symbolic acquisition of the visited tourist site identity (Ciliane-Ceretta et al., 20I4; López-Reyes \& Gómez-Hinojosa, 20I6). In addition, producing and selling butterfly-based souvenirs complement the income of people living in rural zones and help to preserve the species diversity by making people recognize the importance of managing these natural resources (Monterrubio et al., 2013; Morgan-Brown et al., 2010). The tourist merchandise sector is diverse and provides a high potential for local people to participate and, more importantly, it is necessary to promote the sustainable use of the biological material (Báez-Lizarazo et al., 20ı7; López-Serrano et al., 2018; Virapongse et al., 2014).

Diverse studies are required to guide in the sustainable management of wildlife and reduce conflicts between different stakeholders. For example, find the spatial distribution of the target natural resources (Cox et al., 20r4; Jacinto-Padilla et al., 20I7). However, factors other than biotic and climatic ones affect the potential management of ornamental butterflies. Geographic information systems coupled with multicriteria analysis have been used to select tourism-related sites, such as Convention sites (Chen, 2006) and eco-tourism destinations (Dhami et al., 2017; Çetinkaya et al., 2018; Wong \& Fung, 2015). Sustainability is defined by Viso (2005) as "Development that meets the needs of the present generation without compromising the ability of future generations to meet their own needs" and can be viewed as an approach to study composite systems (Salas-Zapata \& Ortiz-Muñoz, 2019). Because analytic hierarchy process is a tool that considers multidimensional components, it is well suited to measure sustainability in diverse fields, like agriculture and forestry, among others (Cinelli et al., 20I4; DiazBalteiro et al., 2017).

An important component in planning for entomotourism activities is to consider the human capital involved in creating and marketing butterfly-based handicrafts. In Mexico, people in rural areas participate in these activities, for example, in religious festivities, people make and wear ankle rattles made of Rotbscbildia cincta Tepper cocoons, collected from wild plants in the Sonoran Desert (Espinoza-López et al., 20I6) and people from Yucatan collect and sell the beetle Zopherus chilensis Gray as live pets or souvenirs (Miss \& Reyes-Novelo, 2009). As tourists are among the main souvenir consumers, it is necessary to take into account factors such as local population, raw material access, and distance from the origin to the market point (International Trade Centre [ITC], 20I4). All of these factors have a spatial variability that needs to be considered to better plan for retail tourism and shopping (Chen, 2007). Therefore, the goal of this study was to explore the potential of the tourist zones in Veracruz as a case study to market butterfly-based handicrafts by people living in the nearby rural areas. 


\section{Methodology}

\section{Tourist zones and influence factors}

The most relevant sites for family-oriented tourism were selected in the state of Veracruz, Mexico (table I) (Secturv, 2015). Health resorts, thermal springs, colonial towns and magical villages were geo-referenced as points while transects were delineated over the beaches accessed by tourists. In each site, a buffer zone with an II km radius was created. The distance is closely equivalent to the minimum one-way ticket cost for public transport, assuming that potential vendors from the rural areas use this mode of transportation. After the tourist zones were delimited, a restriction layer was applied to exclude those areas overlapping with Protected Natural Areas, which by law, have legal restrictions in the use of wildlife. These areas were: Cofre de Perote (CP), Pico de Orizaba (PO), Cañón del Rio Blanco (RB) and Reserva de la Biosfera de Los Tuxtlas (BT) (Comisión Nacional de Áreas Naturales Protegidas [Conanp], 2015).

TABLE 1.

Tourist sites and code, main attractions and services in the state of Veracruz, Mexico

\begin{tabular}{|c|c|c|}
\hline Tourist site/Code & Tourist Attractions & Services \\
\hline Tamiahua/Z01 & Beaches, lagoon, sport fishing & Hotels, local cuisine, seafood \\
\hline Costa Esmeralda/Z02 & Beaches, fishing, turtle camp & Hotels, local cuisine, seafood \\
\hline Tajín/Z03 & $\begin{array}{l}\text { Archaeological site, totonacan crafts, spring } \\
\text { festival }\end{array}$ & Hotels, handicrafts, local cuisine \\
\hline Lechuguillas/Z04 & Beaches & Hotels, local cuisine \\
\hline Villa Rica/Z05 & Beaches & Hotels, local cuisine, seafood \\
\hline Veracruz-Boca del Río, Cempoala/Z06 & $\begin{array}{l}\text { Beaches, sand dunes, bird watching, } \\
\text { archaeological site, carnival, fishing tournament, } \\
\text { museums }\end{array}$ & $\begin{array}{l}\text { Hotels, international airport, handicrafts, local } \\
\text { cuisine, seafood }\end{array}$ \\
\hline Orizaba/Z07 & $\begin{array}{l}\text { Cableway, mountain climbing and hiking, cloud } \\
\text { forest }\end{array}$ & Hotels, local cuisine \\
\hline Tlacotalpan/Z08 & Colonial town, virgin of Candelaria festival & Hotels, local cuisine \\
\hline Tres Zapotes/Z09 & Archaeological site & Local cuisine \\
\hline $\begin{array}{l}\text { Costa de Oro, Monte Pio, } \\
\text { Roca Partida/Z10 }\end{array}$ & $\begin{array}{l}\text { Semivirgin beaches, rappel, ecological reserve, } \\
\text { bird watching }\end{array}$ & Hotels, local cuisine, seafood \\
\hline Catemaco-Salto de Eyipantla/Z11 & Kayak, waterfalls, handmade cigars & Hotels, ecologic cabins, esoterism, local cuisine \\
\hline
\end{tabular}

Source: own elaboration 
TABLE 1.

Tourist sites and code, main attractions and services in the state of Veracruz, Mexico

\begin{tabular}{lll}
\multicolumn{1}{c}{ Tourist site/Code } & \multicolumn{1}{c}{ Tourist Attractions } & Services \\
\hline $\begin{array}{l}\text { San Lorenzo } \\
\text { Tenochtitlán /Z12 }\end{array}$ & Archaeological site & Local cuisine \\
\hline Coatzacoalcos/Z13 & Beaches, international fishing tournament & Hotels, international airport, seafood \\
\hline Zozocolco de Hidalgo/Z14 & Colonial town, local festival & Local cuisine \\
\hline Quiahuiztlán/Z15 & Thermal springs, archaeological site & Local cuisine, seafood \\
\hline Xalapa/Z16 & Colonial towns, museums, alpinism & $\begin{array}{l}\text { Hotels, national airport, local cuisine, } \\
\text { handicrafts }\end{array}$ \\
\hline Coscomatepec/Z17 & Colonial town, rappel & Local cousine, handmade cigars \\
\hline Carrizal/Z18 & Thermal springs & Hotels, local cuisine, health resort \\
\hline Córdoba/Z19 & Museums, Colonial town, ecologic park & Hotels, local cuisine \\
\hline El Zapotal/Z20 & Archaeological site & Local cousine \\
\hline Museo Tuxtleco/Z21 & Olmeca museum & Hotels, local cuisine
\end{tabular}

Source: own elaboration

\section{Information sources}

At each tourist zone, six information layers or factors were calculated and clipped to estimate a weighted linear grading index (Liaghat et al., 2013). These factors were: (I) Area of the zone A (square km), considered to capture or extract butterfly specimens. (2) Tourist number $T$ (Sistema Integral de Información de Mercados Turísticos [SIIMT], 20I3), considered as the potential consumers, near five million tourists visited Veracruz during $20 \mathrm{I}_{3}$, from which 3.5 million had a known destination. The remaining tourist number was allocated across the tourist zones based on a double log, linear regression model related to the population size $P$ :

$$
\ln (T)=\beta 0+\beta 1 * \ln (P)
$$

(3) Total population size $P$ (Instituto Nacional de Estadística, Geografía e Informática [INEGI], 2010) as an indicator of tourist services. (4) Federal roads $R(\mathrm{~km})$, this layer corresponds to the length of national freeways crossing the area, it is relevant as a way to access the zone and because visitors could stop at local towns and buy souvenirs when traveling in their own vehicles. (5) Raw material sources $S$, corresponding to locations with population size higher than 8,000 ; we assumed these locations could be provided with shops and stores to buy the required raw material to make the handicrafts. (6) Butterfly availability $B$, this is a raster layer that contains the potential diversity distribution of 17 butterflies considered of ornamental importance (Jacinto-Padilla et al., 2017). The layer was clipped per each tourist zone and the mean species diversity was computed. The five most preferred butterfly species were: M. helenor, D. gilippus, H. erato, Myscelia ethusa Boisduval, and Siproeta stelenes L. These neotropical species are also commercialized in other countries (Boppré \& Vane-Wright, 20I2; Lopez-Collado et al., 2016). At the next step, values of each factor were normalized between zero and one, and then a weighted sum 
was computed. The weight reflects the relative importance of each factor and the sum corresponds to the grading index (Santé-Riveira et al., 2008).

\section{Weight coefficients and grading system}

We derived the factor weights from a comparison matrix. By consensus, the authors compared pairs of factors using a I to 9 grading scale, I meaning both factors are equally important and 9 implies one of the factors is extremely important (Saaty, 1990). The weights were derived from the normalized eigenvalues of the matrix. Once the weights were estimated, a sum of the factors was computed with the equation:

$$
I_{f}=A^{\prime}{ }_{\mathrm{wa}}+T^{\prime}{ }_{\mathrm{wt}}+P^{\prime}{ }_{\mathrm{wp}}+R^{\prime}{ }_{\mathrm{wr}}+S^{\prime}{ }_{\mathrm{ws}}+B_{\mathrm{wb}}^{\prime}
$$

Where $\mathrm{I}_{f}$ is a suitability index, reflecting the potential of the zone to market handicrafts. In this equation, the $X$, is a normalized factor, ranging from zero to one, and $\mathrm{w}$ is its weight obtained from the comparison matrix. Factor normalization was computed with equation 3 :

$$
X^{\prime} \mathrm{i}=(X \mathbf{1}-\min (X)) /(\max (X)-\min (X))
$$

Equations 2 and 3 were applied to each zone, according to its factor values. The consistency of the comparison matrix was estimated with the Consistency Index (CI), which should be less than 0.10 (Saaty, 1990). We estimated the potential rural population that could benefit from these areas by computing the rural population size in each zone, rural locations have less than 2,500 inhabitants. The bottom and top zones were selected by calculating the quantiles of $\mathrm{I}_{f}$ below 0.20 or above 0.80 , respectively.

\section{Economic value of handicrafts in the tourist zones}

The economic value $(V)$ of the tourist zones was estimated by using a stochastic multiplicative model based on tourist number $(T)$, expenditure of tourist per year $(E)$, proportion of expenditure in handicrafts $(H)$, and the expected market share of butterfly-based handicrafts (M) (adapted from Mundy \& Bullen, 2008):

$$
V=T^{*} E^{*} H^{*} M
$$

$(4)$

We use Monte Carlo simulation ( $\mathrm{n}=50,000$ runs) to obtain the sampling distribution of $V$ based on bootstrap sampling or by using distribution models representing the components of equation 4. Model parameters and 
constant values were obtained from published data or by expert opinions. The analysis were performed using $\mathrm{R}$ v3.5.3 (R Core Team, 2019) and maps were generated using Quantum QGIS v3.6.0 (QGIS Development Team, 20I9).

\section{Results and Discussion}

The relative importance of each factor affecting the potential marketing of butterfly-based handicrafts is presented in table 2. The numbers in the cells represent the relative importance of the row factor related to the column factor. Fractions indicate the contrary, that is, the row factor is less important than the column factor. The computed weights were: $\mathrm{wa}=0.029, \mathrm{wr}=0.425$, ws $=0.088, \mathrm{wb}=0.2002, \mathrm{wp}=0.056$ and $\mathrm{wt}=0.2002$, thus, the most important factors were roads $R$, butterfly species diversity $B$, and tourist number $T$. The $C I$ was 0.09 . Therefore, the comparisons were consistent. On the other hand, based on the tourist number reported by Sectur (2013) (table 3), we adjusted the model: $\ln (T)=-0.0549+1.0375^{*} \ln (P),\left(\mathrm{r}^{2}=0.88 ; \mathrm{F}_{\mathrm{I}, 8}=7.8, \mathrm{p}<0.0 \mathrm{I}\right)$ and estimated the number of visitors for the tourist zones without official data. Population size was obtained from the 2010 national census (INEGI, 20I0).

TABLE 2 .

MATRIX OF THE RELATIVE IMPORTANCE OF FACTORS RELATED TO THE PRODUCTION AND MARKETING OF BUTTERFLY-BASED HANDICRAFTS

\begin{tabular}{ccccccc}
\hline Factor & $\boldsymbol{A}$ & $\boldsymbol{T}$ & $\boldsymbol{P}$ & $\boldsymbol{R}$ & $\boldsymbol{S}$ & $\boldsymbol{B}$ \\
\hline$A$ & 1 & $1 / 6$ & $1 / 4$ & $1 / 7$ & $1 / 5$ & $1 / 6$ \\
$T$ & 6 & 1 & 4 & $1 / 3$ & 4 & 1 \\
$P$ & 4 & $1 / 4$ & 1 & $1 / 7$ & $1 / 3$ & $1 / 4$ \\
$R$ & 7 & 3 & 7 & 1 & 6 & 3 \\
$S$ & 5 & $1 / 4$ & 3 & $1 / 6$ & 1 & $1 / 4$ \\
$B$ & 6 & 1 & 4 & $1 / 3$ & 4 & 1 \\
\hline
\end{tabular}

Source: own elaboration

Note: Tourist zone area $A$, Tourist number $T$, population size $P$, roads length $R$, Services $S$, Butterfly diversity $B$

Once the weights were estimated, equation 2 was applied to grade the tourist zones and were ordered and ranked in table 3, which also presents the non-transformed factor values. The column $r P$ is the rural population living in the respective zone that could benefit from marketing butterflies. The top zones were: $Z_{06}, Z_{13}$, Z ${ }_{02}, Z_{16}$, and $Z_{\text {II }}$ while those in the bottom were: $Z_{09}, Z_{12}, Z_{20}$, Z 0 and $Z_{15}$. Zone $Z_{06}$ presented the highest score in most of the factors. 
TABLE 3.

NON-TRANSFORMED FACTOR VALUES FOR EACH TOURIST ZONE USED TO COMPUTE THE SUITABILITY INDEX IF

\begin{tabular}{cccccccccc}
\hline Zone & $\boldsymbol{A}$ & $\boldsymbol{T}$ & $\boldsymbol{P}$ & $\boldsymbol{R}$ & $\boldsymbol{S}$ & $\boldsymbol{B}$ & $\boldsymbol{I f}$ & $\boldsymbol{O}$ & $\boldsymbol{r P}$ \\
\hline Z06 & 1088 & 2578823 & 1243740 & 83 & 10 & 14 & 0.898 & 1 & 449 \\
Z13 & 512 & 319039 & 349816 & 26 & 7 & 17 & 0.448 & 2 & 91 \\
Z02 & 619 & $* 17364$ & 46047 & 68 & 1 & 13 & 0.443 & 3 & 105 \\
Z16 & 674 & 719100 & 676477 & 16 & 7 & 16 & 0.414 & 4 & 427 \\
Z11 & 479 & 82624 & 171154 & 28 & 2 & 17 & 0.387 & 5 & 374 \\
Z21 & 362 & 34897 & 55595 & 30 & 2 & 16 & 0.351 & 6 & 161 \\
Z19 & 331 & $* 366768$ & 287464 & 9 & 6 & 17 & 0.348 & 7 & 347 \\
Z17 & 346 & $* 36527$ & 99867 & 25 & 2 & 16 & 0.327 & 8 & 281 \\
Z03 & 364 & 423601 & 80521 & 40 & 1 & 12 & 0.292 & 9 & 87 \\
Z05 & 195 & $* 9352$ & 6694 & 46 & 0 & 12 & 0.273 & 10 & 38 \\
Z08 & 365 & $* 17739$ & 10418 & 24 & 0 & 15 & 0.266 & 11 & 16 \\
Z04 & 173 & $* 17860$ & 16528 & 30 & 0 & 14 & 0.259 & 12 & 18 \\
Z18 & 360 & $* 10221$ & 30133 & 28 & 1 & 13 & 0.229 & 13 & 93 \\
Z07 & 234 & $* 312765$ & 103143 & 0 & 5 & 15 & 0.211 & 14 & 198 \\
Z14 & 187 & $* 7277$ & 38485 & 0 & 0 & 17 & 0.206 & 15 & 169 \\
Z10 & 63 & $* 155896$ & 4173 & 0 & 0 & 16 & 0.179 & 16 & 24 \\
Z09 & 366 & 3270 & 21178 & 0 & 0 & 16 & 0.176 & 17 & 86 \\
Z12 & 367 & 3608 & 8512 & 0 & 0 & 16 & 0.176 & 18 & 49 \\
Z20 & 361 & 2346 & 23135 & 0 & 0 & 15 & 0.143 & 19 & 106 \\
Z01 & 910 & $* 237863$ & 127456 & 0 & 1 & 13 & 0.123 & 20 & 203 \\
Z15 & 163 & $* 13998$ & 828 & 2 & 0 & 11 & 0.014 & 21 & 4 \\
\hline
\end{tabular}

\section{Geographic distribution and ranking of the tourist zones}

The map presented in figure I shows the tourist zones and their suitability to produce and market handicrafts. The zone with the highest grade was Zo6; it covers from Chalchihuecan to Anton Lizardo beaches, including the cities of Veracruz and Boca del Rio. The second place was Coatzacoalcos $\left(Z_{13}\right)$. The third was Costa Esmeralda (Z०2). Next was Xalapa ( $\mathrm{Z}_{\mathrm{I}}$ ), and the fifth zone was Catemaco-Salto de Eyipantla ( $\left.\mathrm{Z}_{\mathrm{II}}\right)$. Three zones are located in the central part of the state while Catemaco-Salto de Eyipantla and Coatzacoalcos are located in the south. The less ranked areas correspond to Tres Zapotes (Zo9), San Lorenzo Tenochitlán (ZI2), El Zapotal (Z2o), Tamiahua $\left(Z_{\circ}\right)$, and Quiahuixtla\#n $\left(Z_{15}\right)$. Tourist zones with beaches, waterfalls and a colonial city were the best graded, 
because they have better infrastructure and high butterfly diversity. Regarding the protected zones, there were two non-overlapping zones, CP and PO that locate in the cold, high dry mountain region of Veracruz and relatively far from the tourist sites. Therefore, because of the harsh climatic conditions, they also present low butterfly diversity. On the other hand, the protected area $\mathrm{RB}$ was excluded from zones $\mathrm{Z}_{07}$ and $\mathrm{Z}_{19}$ while the protected area $\mathrm{BT}$ was excluded from zones $Z_{\text {IO }}, Z_{\text {II }}$, and $Z_{21}$. The former is considered to have semi-virgin beaches, $Z_{2 I}$ is between $Z_{10}$ and $Z_{\text {II }}$, this is one of the richest diversity region in Mexico (Koleff \& Soberón, 2008).

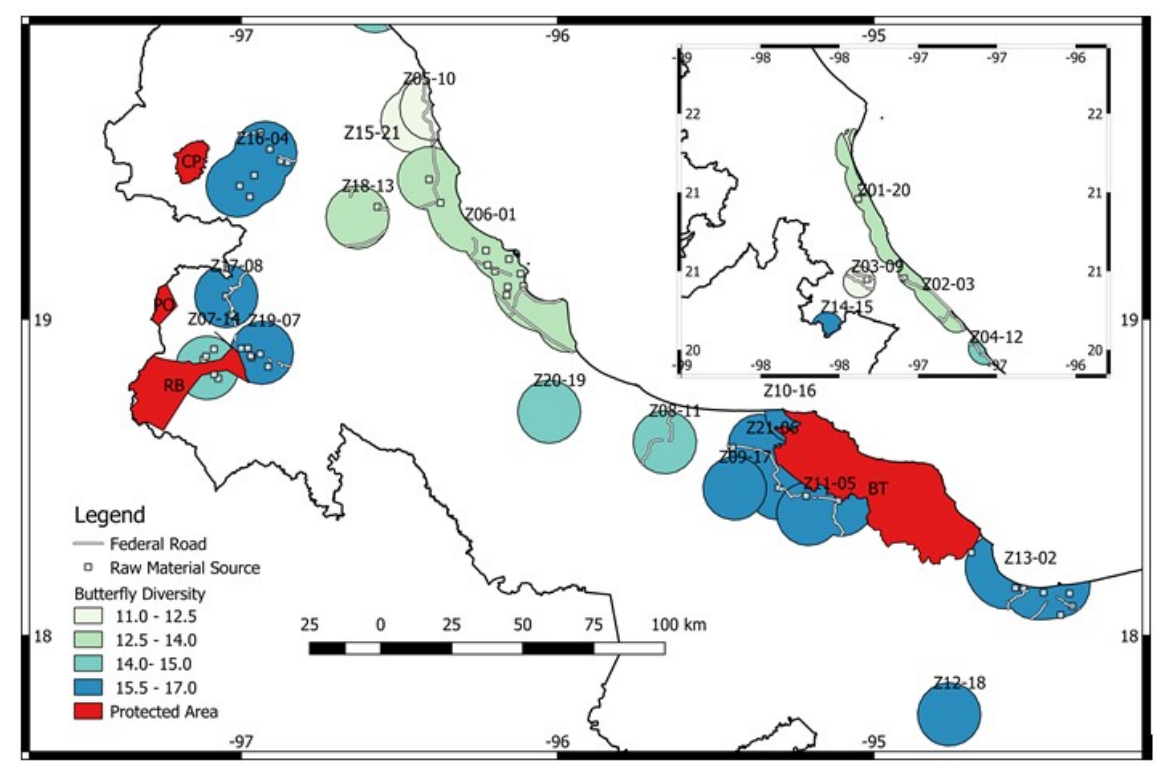

FIGURE 1.

TOURIST ZONES AND THEIR SUITABILITY RANK (Z-O) RELATED TO PRODUCTION AND MARKETING OF HANDICRAFTS BASED ON

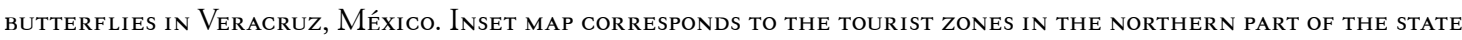
SOURCE: OWN ELABORATION

The grading scale was able to breakdown tourist zones based on their favorability to market butterflies as crafts. For example, zone Zo6 had the highest rank due to its commercial, maritime, and tourist activities that translate into high values for the selected factors (table 3). This zone attracts tourists that like to spend time in the beaches or enjoy other tourist attractions (table I). In this zone, Cruz-Salas (20II) interviewed visitors and local people and found that they are willing to spend from MX $\$ 100$ to MX $\$ 130$ to buy butterfly-based handicrafts. Similar conditions were found in Coatzacoalcos ( $\left.\mathrm{Z}_{\mathrm{I}}\right)$. On the contrary, the colonial city of Xalapa (ZI6) had a high butterfly diversity and was ranked fourth despite being far from the beaches. These zones contrast with some of the less favorable, like Zo9, $Z_{\mathbf{I} 2}$, and Z20, which lack roads and services, even though they have high butterfly diversity (table 3). Therefore, in these sites, transportation and services are less abundant and limit the willingness of tourists to visit them. The least ranked zones have no roads, have few services, small areas and receive few tourists, except for zone Zor that was expected to receive a high number of tourists, according to the regression model (table 3 ).

These results suggest that, in general, roads and services limit the potential to market handicrafts. The restrictions on transportation have been recognized in other studies. For example, places like Michapan, Paso de Ovejas and Tepexilotla, have ecotourism potential, but the lack of roads limit their access (Díaz et al., 2008; Quitano-Díaz et al., 2017). The same happens in other places in the country, where the tourist potential is hampered by difficult access, for example, San Miguel Topilejo, in the valley of Mexico (Carpinteyro-Urbán \& EspinosaCastillo, 20I4). As in other countries, it is suggested that government develop the infrastructure and promote cooperation between tourism actors (Budiarta et al., 2017). A distinguished feature of our work is that, unlike previous research addressing entomotourism activities around and within natural parks and conservation sites 
(Goodwin, 2002; Putri, 2016; Tran et al., 2015), we took into account the different constraints and legal restrictions on the management of natural resources within these kinds of place (Esquivel-Rios et al., 2014). Thus, we adopted a conservative approach by excluding protected sites rich in biodiversity and minimizing the risk of degrading the natural resources as it has been documented in other places like the Bantimurung Nature Recreation Park in Indonesia (Putri, 2016). In the case of the monarch butterfly in Mexico, socio-economic conflicts have been reported between local inhabitants because some of them have rights to develop entomotourism activities while others are not allowed to (Mendoza-Ontiveros et al., 2015). In addition, in the protected areas, it is necessary to have a conservation management plan to perform eco-tourism activities. However, in most cases, there is no such plan, thus leading to a negative balance in protecting the natural resources as it was reported in the Lacandona Selva in Chiapas (Calleros-Rodríguez \& Guevara-Romero, 2016). Therefore, our approach minimized these type of conflicts by excluding protected areas.

On the other hand, the total area of the 2I tourist zones accounts for II\% of the state area, in which 579,104 inhabitants live in the rural areas. We assume that high diversity correlates with abundance, thus, we expect that extracting butterflies in the best ranked zones would not affect natural populations. In addition, previous estimates consider that near $6 \%$ of the economically active population work in tourism, and only $9.6 \%$ of them focus on the handicrafts and souvenirs (INEGI, 2015). Therefore, we estimate that 3,326 persons in the rural areas of these tourist zones could directly work in marketing butterfly-based handicrafts. This total is disaggregated by zones in table 3, but as people already work in this market segment, it should be considered as the best-case scenario. In addition, because of the differences in the marketing potential, we would expect that people living in the top zones $(\mathrm{I}, 446)$ have the best opportunities to develop this activity and because there is an already established handicraft marketing sector, people will need to compete and develop marketing strategies to attract the consumers. Also, our objective was to address people living in the rural areas near these tourist zones because they are best located to collect or capture ornamental butterflies (Lopez-Collado et al., 20I6), but it does not exclude inhabitants of urban areas because some of the target Neotropical butterflies also thrive in those areas as well (Jacinto-Padilla, 20I6). Anecdotal evidence indicates that in zone 16 a single person sells butterfly-based handicrafts, thus highlighting both the potential of this activity and the lack of people dedicated to it. A previous research estimated that most visitors $(74 \%)$ have the intention to buy this type of merchandise (Lopez-Collado et al., 20I6).

The favorability index of the assessment system integrates the three pillars of sustainability. Tourist area, number of tourists and row material sources are part of the economic sphere. Socially speaking, the size of the rural population and roads are included. Also, in the environmental component, protected natural areas and the availability of non-threatened butterfly resources were included. Thus, our model conciliates the economic development and the conservation of the biological resources. However, much work is needed and some challenges are expected to be overcome in order to establish a butterfly-based handicraft market. First, the need of training because this a new activity (Abisuga-Oyekunle \& Fillis, 2017). Another challenge is to evaluate the preferences of visitors to buy different handicraft articles like earrings, frames or key chains. However, some knowledge has been generated on this issue because a previous work focused on the willingness to pay for different handicraft models and preferences. It was found that butterfly frames, pendants, lamps, picture frames and key chains were preferred (Cruz-Salas, 20II). Other countries, like Costa Rica and Papua New Guinea are examples of success in the sustainable use of the butterfly resource by rural communities. In part due to public policies and legislation that regulate the value chain, from the rearing of butterflies, their commercialization, diversification in products and byproducts from the wings of butterflies (Montero, 2007; Hutton, 1985; New, 1994). Therefore, in Mexico is essential to regulate the management and use of the butterfly resource, because there are no restrictions on the capture of rare species when their populations are low, which may lead to be placed on the Red List index. Currently, the Official Mexican Standard NOM-059 (Secretaría de Medio Ambienté y Recursos Naturales [Semarnat], 2010) only protects the monarch and the Esperanza butterflies. 
Finally, an important future step is to gain market share because there is an established handicraft component within the tourism activities (Jiménez-Castañeda et al., 2009). Therefore, as people in the rural locations usually have low income, it is highly advisable that government policies and activities support the initial stage in introducing new products or services (ITC, 20I4; López-Delfín et al., 20I8). Though some challenges have been outlined, it is difficult to generalize because artisans face different obstacles depending on their activity (Harris, 2014). For example, "Needle and Thread" artisans in India lack education, have low economic resources, and the institutional framework is weak (Shah \& Patel, 2017). Pro poor tourism strategies aim to benefit marginalized urban and rural populations by increasing their opportunities in the tourism sector. However, it should be integrated into mainstream research (Harrison, 2008). Thus, while our study focused on populations in the rural communities, it also considers how they "fit" within the current tourism activities and recognizes its limitations.

\section{Economic value of handicrafts in the tourist zones}

The value of the handicraft market was estimated based on the model parameters and constants presented in table 4. Random variability was generated by bootstrap sampling of historic values, like numbers of tourirsts visiting the state of Veracruz and the proportion of expenditure allocated to buy handicrafts and souvenirs. The percentage of expenditure in handicrafts is close to the $5.5 \%$ value reported in tourism-related handicraft in Ethiopia (ITC, 20I4). We estimated the variability of market share by consensus and used the Pert distribution to model such variable while we obtained a single value for the expenditure per tourist from a national survey (table 4). The sampling distribution of the potential annual value of butterfly-based handicrafts is shown in figure $2(\mathrm{~A})$. The distribution is right-skewed (skewness $=0.03 \mathrm{I}$ ) and has a median value of US $\$ 259,482$ with a $95 \%$ confidence interval between US \$122,273 and US \$438,97I. The economic value for each tourist zone is presented in figure 2(B), the top $20 \%$ zones accounted for $69 \%$ of the total economic value. It is interesting to note that zone 03 , Tajin, accounts for $7.8 \%$ of the potential economic value but due to the relatively low contribution of the other factors, it is ranked halfway in the grading scale. However, as mentioned before, to promote rural inhabitants into the souvenir market requires additional planning and training efforts, like identifying the value chain components and their challenges, for example, by promoting innovation and new designs or by overcoming the lack of suitable market outlets (ITC, 20I4). Training programs are also required to enhance the competitiveness of the involved people in the established handicraft and souvenir market (ITC, 20I4; Saragos-Méndez \& Patriganni, 20I2). In particular, training and certification by the government to achieve primary production and value addition is recommended, as occurs in Costa Rica where around 400 families produce butterflies (Montero, 2007; Umaña, 2019). Some of these issues have been addressed in Veracruz, like assessing the value and preference of different butterfly-based handicrafts as mentioned before (Cruz-Salas, 20II). Another example of the economic assessment is the use of pine needles to make handicrafts in Perote, Veracruz, where it was reported that the profit was similar to the national minimum wage (López-Serrano et al., 2018). Though we emphasize the economic aspect of handicraft trading, other non-mensurable values are associated to souvenirs, that is, they have sign, spiritual, cultural and use values (Paraskevaidis \& Andriotis, 2015). For example, souvenirs are part of the cultural heritage of the Yoreme people in Sonora; they use the cocoons of R. cinta, a saturniid moth, to make ankle rattles used in ceremonial dances in religion tourism (Espinoza-López et al., 2016; Peigler \& Maldonado, 2005). 
TABLE 4.

VARIABLES, CONSTANTS, AND PARAMETERS OF THE DISTRIBUTION MODELS RELATED TO THE ESTIMATION OF THE ECONOMIC VALUE OF BUTTERFLY-BASED HANDICRAFTS IN VERACRUZ, MEXICO

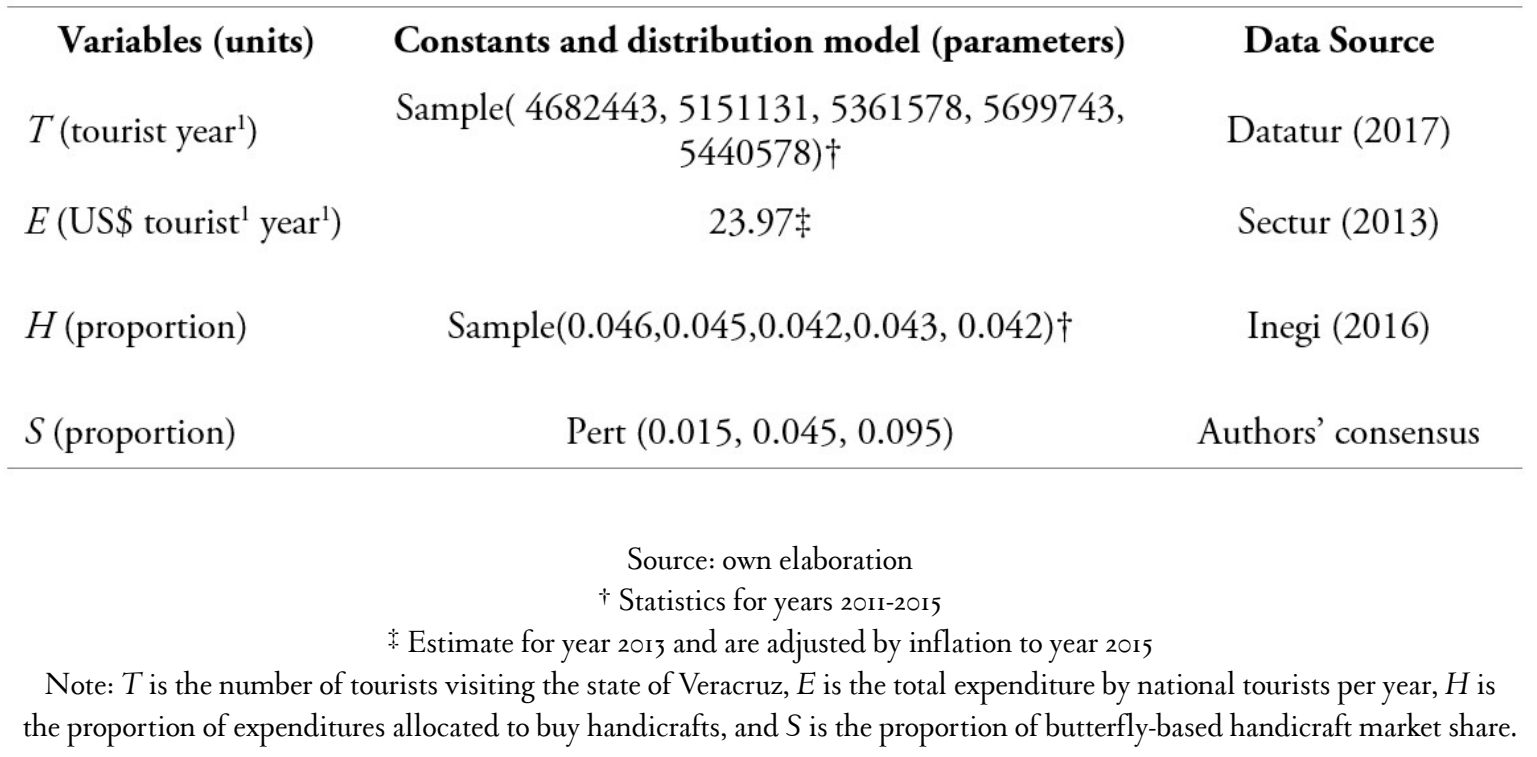



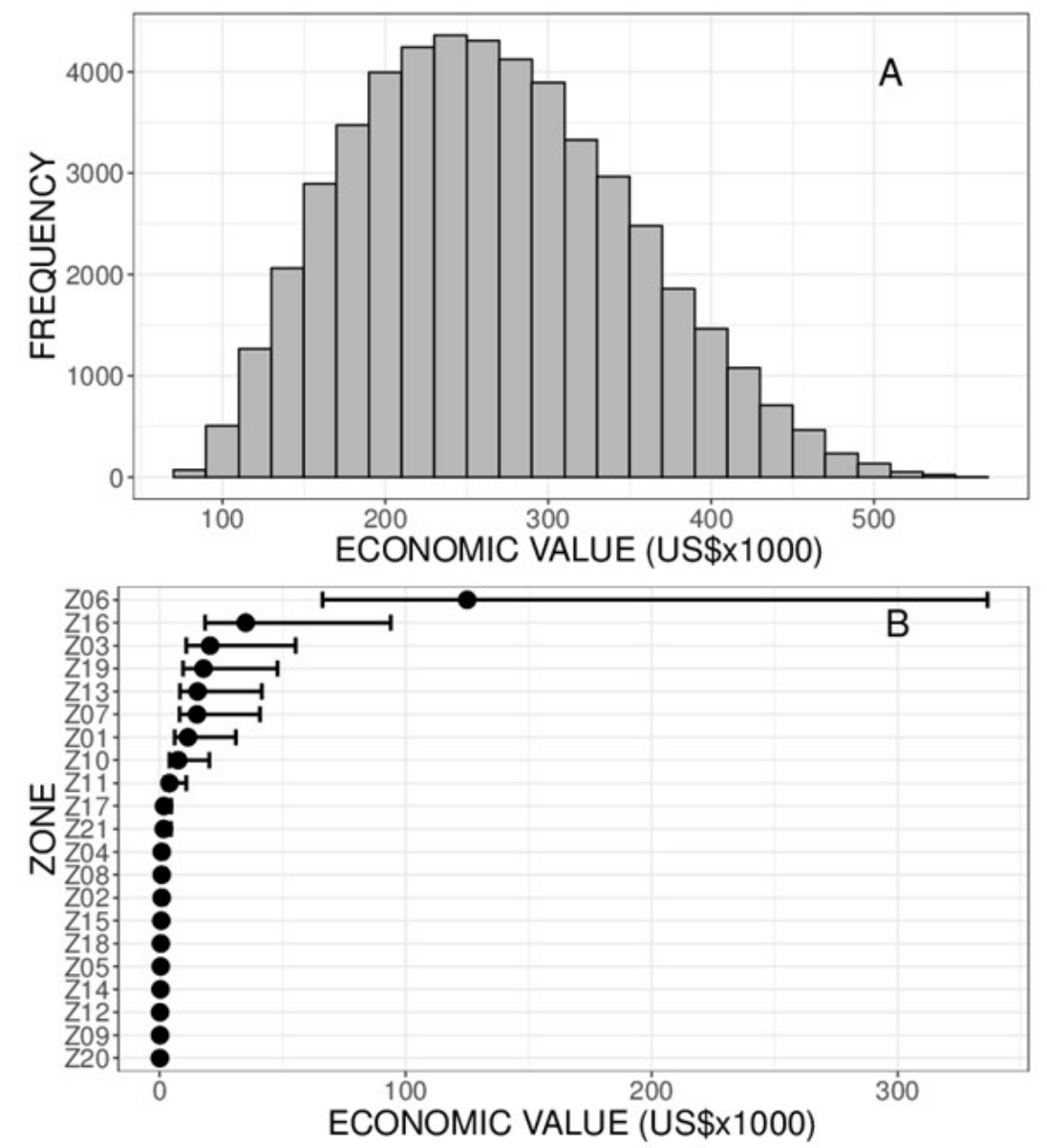

FIGURE 2.

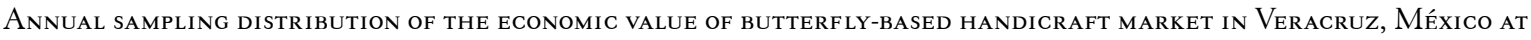
STATE LEVEL (A) AND 95\% CONFIDENCE INTERVAL OF THE ECONOMIC VALUE PER TOURIST ZONE, POINT IS THE MEDIAN VALUE (B)

SOURCE: OWN ELABORATION

Regarding the extraction of butterflies to make souvenirs, the information about the risks involved in marketing butterflies is scarce. Some guidelines have been proposed to mitigate risks related to the Butterfly House Industry, which is a network of stakeholders centered on butterfly exhibition centers, usually located in temperate places like the United States and Europe, and populated with species obtained from breeding and farming activities in tropical countries (Boppré \& Vane-Wright, 20I2; Veltman, 2009). In the case of butterfly-based souvenirs, it is a market segment that demands less management because it uses preserved or dissected specimens, which can be collected in different ways. Then, rearing and farming are not essential (Gómez-S, 2006). This research also considers species that have a wide distribution in the country (Jacinto-Padilla et al., 20I7) and not listed as protected species, like the monarch butterfly and the Esperanza

butterfly (Semarnat, 2010). By excluding reserves, protected zones, and threatened species, this approach diminishes some issues found in other regions, like restricted access to tourists and potential reduction of butterfly populations (Goodwin, 2002; Putri, 2016).

As in other countries where butterflies are processed to create handicrafts, there is also a broad range of souvenirs that do not necessarily involve using actual butterflies. By tradition, people in Veracruz make souvenirs using the sea ecosystem as inspiration. Therefore, people can create t-shirts, mugs, and key rings with butterfly and insect 
themes (Lopez-Collado et al., 20I6). This is occurring in the states of Puebla, Sinaloa and Sonora, where artisans are organized to use local natural resources to diversify the supply of souvenirs in rural areas and to increase their income (Hernández-Soto, 20I4; Jouault \& Pulido-Madariaga, 20I4; Romero-García, 20I4). Likewise, artisanship activities are considered as a cultural heritage that can support the economy in rural communities, for example, through religious tourism (Rivera-Cruz et al., 2008). The sustainability of butterfly-based handicraft marketing will depend upon the awareness of potential vendors to abide by the conservation practices aimed to protect the native butterfly populations and the willingness of tourist to accept management regulations (Bach \& Burton, 2017).

Although this research addresses the tourism sector, there are other potential markets to expand the sales of butterfly-based handicrafts. For example, regional festivals and shows, public places like parks or gastronomic routes where people gather for eating, leisure and resting. Another option is by including butterflies in landscape management to create spaces for visitors to attend and enjoy these insects (Lemelin, 2009; Monterrubio et al., 2013). This activity requires a different spatial analysis to take into account the natural habitat and factors that enhance the potential of the butterflies to thrive in their natural conditions, that is, to diversify ecotourism activities (Çetinkaya et al., 20I8; Wong \& Fung, 20I5). Rearing and selling live butterflies is a current, popular activity, which uses newer media for advertising like the internet. Thus, additional research is needed to address issues related to the economic value of these activities, the effect of specimen extraction on conservation and the competitiveness of this new activity within the established market. However, we consider this research as a first approach where specific factors were quantified and combined to better assess the opportunities of people to use these local natural resources in a planned way.

\section{Conclusion}

This research provides an exploratory, empirical analysis framework to model different factors that affect the butterfly-based handicraft marketing potential, using tourist zones of the state of Veracruz, Mexico, as a case study. Current practices of producing and marketing butterfly-based handicrafts and entomotourism activities have been developed to take advantage of local biodiversity and tourist demand, usually in biosphere reserves like the "sanctuaries" of the monarch butterfly or tropical reserves like those in Southeast Asia. However, marketing and protecting natural resources lead to conflicts and opposing goals. This study considered spatial, economic, social, legal and biotic factors to grade the tourist zones aimed to enhance the opportunities of rural communities in this activity. The results indicated that roads, butterfly species diversity, and visitors increased the ranking of tourist zones while excluding protected areas enhance the sustainability of these natural resources by constraining the target zones and minimizing the risk of overexploitation. The best areas were beach zones and colonial towns that have most of the resources and services required. The analysis allowed estimating the number of persons from rural communities that could engage in this activity with a minimum transport cost. Also, a stochastic economic value of butterfly-based handicrafts across all the tourist zones was derived based on the probability theory and assuming a varying market share. We are aware that this study is dependent on the local, particular data collected and processed, and, if applied to other places, the results would differ, but we expect the differences reflect inherent potential conditions for marketing butterfly-based handicrafts at a strategic level. In addition, this study could serve as a starting point to help discriminate and guide in selecting the tourist zones with the highest likelihood to succeed. However, we also recognize the additional challenges to overcome in order to establish this tourist market segment. It includes to train people in collecting, rearing and processing butterflies, explore the offer of handicrafts in festivals, fairs, and carnivals within the favored zones, determine the market chain components and promote public policies intended to ensure the rational use of this resource. Future research should also address environmental 
aspects such as the effect of climate change on the distribution of butterfly species and their plant hosts, and assess the management of butterflies within their natural habitat as recreational components of ecotourism.

\section{Acknowledgments}

We thank Mr. José Luis Quino Velázquez and Mr. C. Rogelio Quino Rosas, management officers of Salto de Eyipantla waterfall park, for providing tourist statistics.

\section{References}

Abisuga-Oyekunle, O. A., \& Fillis, I. R. (2017). The role of handicraft micro-enterprises as a catalyst for youth employment. Creative Industries Journal, Io(I), 59-74. https://doi.org/10.1080/17510694.2016.1247628

Bach, L., \& Burton, M. (2017). Proximity and animal welfare in the context of tourist interactions with habituated dolphins. Journal of Sustainable Tourism, 25(2), I81-197. https://doi.org/10.1080/09669582.2016.1195835

Báez-Lizarazo, M. R., Santoro, F. R., Albuquerque, U. P., \& Ritter, M. R. (2017). Aquatic vascular plants as handicraft: a case study in southern Brazil. Acta Botanica Brasilica, 32(0), 88-98. https://doi.org/10.1590/010 2-33062017abbo282

Boppré, M., \& Vane-Wright, R. I. (2012). The butterfly house industry: conservation risks and education opportunities. Conservation and Society, Io(3), 285-305. https://doi.org/10.4103/0972-4923.101831

Budiarta, I. P., Ardiasa, I. K., Nurjaya, I. W., \& Kanca, I. N. (2017). Potency and development of ecotourism of butterfly park in Sesandan Village, Tabanan Regency. Soshum: Jurnal Social dan Humaniora, 7(3), 288-297. htt ps://doi:I0.31940/soshum.v7iz.704

Buenaño-Allauca, M. P., Soria-Flores, E. R., \& Galiano-Andrade, N. E. (2017). Contribución del sistema artesanal en el desarrollo turístico local: caso Otavalo. Revista Publicando, 4(2), 267-277. https://revistapublicando.org/ revista/index.php/crv/article/view/490

Calleros-Rodríguez, H., \& Guevara-Romero, M. L. (2016). La Comunidad Zona Lacandona y las áreas naturales protegidas en su territorio. Desenvolvimento e Meio Ambiente, 38, 155-177. https://doi.org/10.5380/dma.v38io.45 362

Camarena-Gómez, D. M., Robles-Baldenegro, M. E., Velarde-Mendívil, A. T., \& Erquizio-Espinal, A. (20I4). Los alimentos tradicionales como alternativa de turismo rural: el caso de Ures, Sonora. AgroProductividad, $7(4)$, 42-48. https://revista-agroproductividad.org/index.php/agroproductividad/article/view/537/4I4

Carpinteyro-Urbán, S. L., \& Espinosa-Castillo, M. (20I4). El potencial natural de la reserva ecológica comunitaria San Miguel Topilejo para uso turístico. AgroProductividad, 7(4), 35-45. http://revista-agroproductividad.org/ index.php/agroproductividad/article/view/536/413

Çetinkaya, C., Kabak, M., Erbas, M., \& Özceylan, E. (2018). Evaluation of ecotourism sites: a GIS-based multicriteria decision analysis. Kybernetes, 47 (8), I664-1686. https://doi.org/10.1108/K-10-2017-0392

Chen, C. F. (2006). Applying the analytical hierarchy process (AHP) approach to convention site selection. Journal of Travel Research, 45(2), 167-174. https://doi.org/10.1177/0047287506291593

Chen, R. J. C. (2007). Geographic information systems (GIS) applications in retail tourism and teaching curriculum. Journal of Retailing and Consumer Services, I4(4), 289-295. https://doi.org/10.1016/J.JRETCONSE R.2006.07.004 
Ciliane-Ceretta, C., Zamberlan dos Santos, N. R., \& Flores dos Santos, V. (2014). La valoración de las artesanías en el sur de Brasil a través del turismo. Estudios y Perspectivas en Turismo, 23(4), 668-684. https://www.redalyc .org/articulo.oa?id=I80732145002

Cinelli, M., Coles, S. R., \& Kirwan, K. (2014). Analysis of the potentials of multi criteria decision analysis methods to conduct sustainability assessment. Ecological Indicators, 46, 138-148. https://doi.org/10.1016/j.ecolind.20I4. 06.011

Comisión Nacional de Áreas Naturales Protegidas (Conanp). (2015). Información espacial. Gobierno de México. h ttp://sig.conanp.gob.mx/website/pagsig/info_shape.htm

Cox, C., Morse, W., Anderson, C., \& Marzen, L. (2014). Applying public participation geographic information systems to wildlife management. Human Dimensions of Wildlife, 19(2), 200-214. https://doi.org/10.1080/108712 09.2014 .871663

Cruz-Salas, L. L. (201I). Análisis socioeconómico de mariposas de Veracruz para uso artesanal (MSc. Thesis). Colegio de Postgraduados, Campus Veracruz, México.

Sistema Nacional de la Información Estadística del Sector Turismo de México (DATATUR). (2016). Compendio estadístico del turismo en México 20I6. Retrieved from http://www.datatur.sectur.gob.mx/SitePages/Compend ioEstadistico.aspx

Sistema Nacional de la Información Estadística del Sector Turismo de México (Datatur). (20I7). Información turística por entidad federativa. Gobierno de México. http://www.datatur.sectur.gob.mx/ITxEF/ITxEF_VER.aspx

De Mello, C. L., \& Ciliane-Ceretta, C. (2015). El souvenir artesanal y la promoción de la imagen del lugar turístico. Estudios y Perspectivas en Turismo, 24(2015), I88-204. https://www.estudiosenturismo.com.ar/PDF/V24/No2/ v24nzaor.pdf

Dhami, I., Deng, J., Strager, M., \& Conley, J. (2017). Suitability-sensitivity analysis of nature-based tourism using geographic information systems and analytic hierarchy process. Journal of Ecotourism, I6(I), 4I-68. https://do i.org/10.1080/14724049.2016.1193186

Díaz, I., Nava, M., Gallardo, F., García, J., \& Fajerson, P. (2008). Potencial para turismo alternativo del municipio de Paso de Ovejas, Veracruz. Tropical and Subtropical Agroecosystems, 8(2), 199-208. http://www.redalyc.org/pd f/939/93980210.pdf

Diaz-Balteiro, L., González-Pachón, J., \& Romero, C. (2017). Measuring systems sustainability with multi-criteria methods: a critical review. European Journal of Operational Research, 258(2), 607-16. https://doi.org/10.1016/j.ej or.2016.08.075

Espinoza-López, P. C., Bañuelos-Flores, N., \& López-Reyes, M. (2016). Entre capullos de mariposas y fiestas. Hacia una alternativa de turismo indígena en El Júpare, Sonora, México. Estudios Sociales, 24(47), 3II-344. https:// www.redalyc.org/articulo.oa?id=417440030I2

Esquivel-Rios, S., Cruz-Jiménez, S., Zizumbo-Villarreal, L., \& Cadena-Inostroza, C. (20I4). Gobernanza para el turismo en espacios rurales. Reserva de la Biosfera Mariposa Monarca. Revista Mexicana de Ciencias Agrícolas, 5(9), 1631-1643. https://doi.org/10.29312/remexca.voig.1053

Fagua, G., Gómez, R., \& Gómez, M. A. (2002). Estudio de viabilidad para la cría de mariposas y coleópteros como alternativa productiva para la regeneración del bosque en territorios dedicados a la siembra de cultivos ilícitos en San José del Guaviare (Colombia). Aracnet 9 -Boletín Sociedad Entomológica Aragonesa, 30, 223-224. http://e ntomologia.rediris.es/aracnet/9/proyectoi/guaviare/ 
Gómez-S, R. (2006). Plan de manejo propuesto para la cría de mariposas promisorias como alternativa productiva para comunidades indígenas de la Amazonia colombiana. Boletín Sociedad Entomológica Aragonesa, 38, 45I-460. http://sea-entomologia.org/PDF/GeneraInsectorum/GE-0057.pdf

Goodwin, H. (2002). Local community involvement in tourism around National Parks: opportunities and constraints. Current Issues in Tourism, 5(3), 338-360. https://doi.org/10.1080/13683500208667928

Harris, J. (2014). Meeting the challenges of the handicraft industry in Africa: evidence from Nairobi. Development in Practice, 24(I), I05-II7. https://doi.org/I0.I080/096I4524.20I4.867478

Harrison, D. (2008). Pro-poor tourism: a critique. Third World Quarterly, 29(5), 85I-868. https://doi.org/10.1080/० I436590802105983

Hernández-Soto, J. A. (2014). Perspectivas del turismo rural en Santa Ana Teloxtoc, Tehuacán; Puebla, México. Agroproductividad, 7(4), 64-70. https://revista-agroproductividad.org/index.php/agroproductividad/article/v iew/540/417

Hutton, A. F. (1985). Butterfly farming in Papua New Guinea. Oryx, 19(3), 158-162. https://doi.org/10.1017/So030 605300025333

Instituto Nacional de Estadística, Geografía e Informática (Inegi). (2010). Censo de población y vivienda 2010. México. Inegi. https://inegi.org.mx/programas/ccpv/2010/

Instituto Nacional de Estadística, Geografía e Informática (Inegi). (2015) Anuario estadístico y geográfico de Veracruz de Ignacio de la Llave 2015. México. Inegi. http://internet.contenidos.inegi.org.mx/contenidos/productos/pr od_serv/contenidos/espanol/bvinegi/productos/nueva_estruc/AEGPEF_2015/702825077297.pdf

Instituto Nacional de Estadística, Geografía e Informática (Inegi). (2016). Economía. Sectores económicos. Turismo. Servicios. Composicion. México. Inegi. http://wwwz.inegi.org.mx/sistemas/temas/default.aspx?s=est\&c=23824

International Trade Centre (ITC). (20I4). Inclusive tourism: linking the handicraft sector to tourism markets-2 ${ }^{\text {nd }}$ edition. ITC. http://www.intracen.org/uploadedFiles/intracenorg/Content/Publications/H_OED_Public\%2oInf ormation_Publications_Technical\%2op.pdf

Jacinto-Padilla, J.. (2016). Distribución de mariposas ornamentales en México: un estudio de caso para Veracruz (MSc. Thesis). Colegio de Postgraduados, Campus Veracruz, México.

Jacinto-Padilla, J., Lopez-Collado, J., Lopez-Collado, C. J., \& García-García, C. G. (2017). Species distribution modeling for wildlife management: ornamental butterflies in México. Journal of Asia-Pacific Entomology, 20, 627-636. https://doi.org/10.1016/j.aspen.2017.03.026

Jiménez-Castañeda, J .C., Domínguez-Hernández, M. L., \& Martínez-Castro, C. J. (2009). Estrategias y competitividad de los negocios de artesanía en México. Pensamiento y Gestión, 26, 165-190. http://www.redal yc.org/pdf/646/64612291008.pdf

Jouault, S., \& Pulido-Madariaga, E. (2014). Turismo solidario y empoderamiento: el caso de Ek Balam, Yucatán, México. Agroproductividad, 7(4), 24-29. https://revista-agroproductividad.org/index.php/agroproductividad/ article/view/534/4II

Koleff, P., \& Soberón, J. (2008). Patrones de diversidad espacial en grupos selectos de especies. En J. Sarukhán (Ed.), Capital natural de México, vol. I: conocimiento actual de la biodiversidad (pp. 323-364), CONABIO.

Lemelin, H. (2009). Goodwill hunting: Dragon hunters, dragonflies and leisure. Current Issues in Tourism, I2(5-6), 553-571. https://doi.org/10.1080/13683500802346169

Liaghat, M., Shahabi, H., Deilami, B. R., Ardabili, F. S., Seyedi, S. N., \& Badri, H. (2013). A multi-criteria evaluation using the analytic hierarchy process technique to analyze coastal tourism sites. APCBEE Procedia, 5(2013), 479-485. https://doi.org/10.1016/j.apcbee.2013.05.081 
Lopez-Collado, J., Cruz-Salas, L. L., García-Albarado, J. C., Platas-Rosado, D. E., \& Calyecac-Cortero, G. H. (20I6). Size doesn't matter but color does: preference of neotropical butterfly species to make souvenirs. Journal of Entomology and Zoology Studies, 159(45), 159-165. https://www.entomoljournal.com/archives/?year=2016\&vol $=4 \&$ issue $=5 \&$ ArticleId $=1185$

López-Delfín, I. P., Piñar-Álvarez, M. A., Negrete-Ramírez, J. A., Wojtarowski-Leal, A., \& El Colegio de Veracruz. (20I8). Public policy to promote sustainable tourism in the state of Veracruz, Mexico. En W. Leal-Filho., R. Noyola-Cherpitel., P. Medellín-Milán., \& V. Ruiz-Vargas (Eds.), Sustainable development research and practice in Mexico and elected latin american countries. World Sustainability Series (pp. 423-438). Springer. https://doi.org /10.1007/978-3-319-70560-6_27

López-Reyes, S., \& Gómez-Hinojosa, C. (2016). Arte vivo en los tejidos de Venustiano Carranza, Chiapas, México. Revista Espacio I+D Innovación Más Desarrollo, 5(II), 35-51. https://doi.org/I0.31644/IMASD.II.2016.a02

López-Serrano, Y., Pineda-López, M. R., \& Sánchez-Velásquez, L. R. (2018). Is the use of a non-timber forest resource compatible with environmental conservation? The case of handicraft production at the Cofre de Perote National Park, Mexico. Small-Scale Forestry, 17, 57-69. https://doi.org/ı0.1007/sII842-017-9375-0

Mendoza-Ontiveros, M. M., Figueroa-Hernández, E., \& Godínez-Montoya, L. (2015). Turismo comunitario propobre en el ejido El Rosario, Reserva de la Biosfera de la Mariposa Monarca. El Periplo Sustentable, 29, 92-II9. https://rperiplo.uaemex.mx/article/view/4907/3466

Miss, J. V, \& Reyes-Novelo, E. (2009). Observaciones sobre la biología del maquech, Zopherus chilensis Gray, I832 (Coleoptera: Zopheridae) en Yucatán México. Arquivos Entomolóxicos Galegos, 2, 7-17. https://dialnet.unirioja .es/servlet/articulo?codigo $=4037313$

Montero, R. J. (2007). Manual para el manejo de mariposarios. Instituto Nacional de Biodiversidad.

Monterrubio, J. C., Rodríguez-Muñoz, G., \& Mendoza-Ontiveros, M. M. (2013). Social benefits of ecotourism: the monarch butterfly reserve in Mexico. Enlightening Tourism. A Pathmaking Journal, 3(2), 105-124. http://ri.u aemex.mx/bitstream/handle/20.500.11799/40535/Artículo. Social benefits of ecotourism Enlightening.pdf? sequence=I\&isAllowed=y

Morgan-Brown, T., Jacobson, S. K., Wald, K., \& Child, B. (2010). Quantitative assessment of a Tanzanian integrated conservation and development project involving butterfly farming. Conservation Biology, 24(2), 563-572. https://doi.org/10.111I/j.1523-1739.2009.01433.x

Mulanovich, D. C. A. J. (2007). Mariposas: guía para el manejo sustentable de las mariposas del Perú. Prompex, IIAP y GTZ.http://repositorio.iiap.gob.pe/bitstream/IIAP/80/2/Mulanovich_libro_2007.pdf

Mundy, K., \& Bullen, S. G. (2008). Estimating market potential: is there a market? (Report No. Business Tools-5). NC state university cooperative extension. https://cals.ncsu.edu/are-extension/wp-content/uploads/sites/27/20 I8/03/Estimating-Market-Potential.pdf

New, T. R. (1994). Butterfly ranching: sustainable use of insects and sustainable benefit to habitats. Oryx, 28(3), I69-172. https://doi.org/10.1017/S0030605300028520

Organization for Economic Cooperation and Development (OECD). (2017). Tourism Policy Review of Mexico, OECD Studies on Tourism. Gobierno de México. https://www.datatur.sectur.gob.mx/SiteAssets/SitePages/DocsPu bs/TOURISM_POLICY_REVIEW_MEXICO.pdf

Paraskevaidis, P., \& Andriotis, K. (2015). Values of souvenirs as commodities. Tourism Management, 48(2015), I-IO. h ttps://doi.org/I0.I0I6/j.tourman.20I4.10.0I4 
Peigler, R. S., \& Maldonado, M. (2005). Uses of cocoons of Eupackardia calleta and Rotbschildia cincta (Lepidoptera: Saturniidae) by Yaqui indians in Arizona and Mexico. Nachrichten Des Entomologischen Vereins Apollo, 26(3), III-II9. https://www.zobodat.at/pdf/NEVA_26_ori-orig.pdf

Putri, I. A. S. L. P. (2016). Handicraft of butterflies and moths (Insecta: Lepidoptera) in bantimurung nature recreation park and its implications on conservation. Biodiversitas, I7(2), 823-831. https://doi.org/10.13057/b iodiv/di70260

QGIS Development Team. (2019). QGIS geographic information system. Open source geospatial foundation (Version 3.6.o). https://www.qgis.org/en/site/forusers/download.html

Quitano-Díaz, D., Pavón-León, L. M., \& Flores-de la Cruz, S. (2017). Posibilidades y vínculos actuales para el desarrollo regional de Veracruz. Revista Internacional de Desarrollo Regional Sustentable, 2(I-2), 20-38. http://rin deresu.com/index.php/rinderesu/article/view/24/26

R Core Team. (2019). R: a language and environment for statistical computing (Version 3.5.3). Vienna, Austria. https://w ww.r-project.org/

Rivera-Cruz, M. L., Alberti-Manzanares, P., Vázquez-García, V., \& Mendoza-Ontiveros, M. M. (2008). La artesanía como producción cultural susceptible de ser atractivo turístico en Santa Catarina del Monte, Texcoco. Convergencia, I5(46), 225-247. http://www.scielo.org.mx/scielo.php?script=sci_arttext\&pid=SI405-I43 $52008000100010 \& \operatorname{lng}=e s \& t \operatorname{lng}=e s$.

Romero-García, O. S. (20I4). Capacidad de carga turística de la reserva ecológica mineral de nuestra Señora de Cosalá, Sinaloa, México. Agroproductividad, 7(4), 30-34. http://revista-agroproductividad.org/index.php/agr oproductividad/article/view/535/412

Saaty, T. L. (1990). How to make a decision: the analytic hierarchy process. European Journal of Operational Research, 48(I), 9-26. https://doi.org/10.1016/0377-2217(90)90057-I

Salas-Zapata, W. A., \& Ortiz-Muñoz, S. M. (2019). Analysis of meanings of the concept of sustainability. Sustainable Development, $27(\mathrm{I})$, I53-16r. https://doi.org/10.1002/sd.I885

Santé-Riveira, I., Crecente-Maseda, R., \& Miranda-Barrós, D. (2008). GIS-based planning support system for rural land-use allocation. Computers and Electronics in Agriculture, 63(2), 257-273. https://doi.org/10.1016/j.compag.2 008.03 .007

Saragos-Méndez, J., \& Patriganni, L. D. (2012). Cría de mariposas diurnas, perspectivas para la producción de artesanías y desarrollo del ecoturismo, en una comunidad del estado de Tabasco, México. En J. G. Chan-Quijano., R. Martínez-Yañez., \& A. Espinoza-Tenorio (Eds.), Manejo sostenible de los recursos naturales; conservación y experiencias (pp. 62-85). El Colegio de la Frontera Sur y Seminario en Manejo de Recursos Naturales.

Secretaría de Turismo (Sectur). (2013). Encuesta nacional de gastos turísticos en los hogares 2013. Gobierno de México. h ttp://www.datatur.sectur.gob.mx/SitePages/Iniciobanner2.aspx//

Secretaría de Turismo y Cultura (Secturv). (2015). Regiones turísticas. Gobierno de México. http://www.veracruz.g ob.mx/turismo/regiones-turisticas/

Secretaría de Turismo y Cultura (Secturv). (2018). Veracruz! Gobierno de México. http://www.veracruz.mx

Secretaría de Medio Ambienté y Recursos Naturales (Semarnat). (2010). Norma Oficial Mexicana NOM-059SEMARNAT-20I0. Protección ambiental-especies nativas de México de flora y fauna silvestres-categorías de riego y especificaciones para su inclusión, exclusión o cambio-lista de especies en riesgo. Diario Oficial de la Federación. https:/ /www.profepa.gob.mx/innovaportal/file/3552/r/nom-059-semarnat-2010_30-dic-2010.pdf 
Shah, A., \& Patel, R. (2017). Problems and challenges faced by handicraft artisans. Voice of Research, 6(I), 57-6r. htt p://www.voiceofresearch.org/doc/Jun-2017/Jun-2017_I4.pdf

Sistema Integral de Información de Mercados Turísticos (SIIMT). (2013). Siimt.com. http://www.siimt.com/

Tran, D. T. T., Nomura, H., \& Yabe, M. (2015). Tourists' preferences toward ecotourism development and sustainable biodiversity conservation in protected areas of Vietnam-the case of Phu My protected area. Journal of Agricultural Science, 7(8), 8I-89. https://doi.org/10.5539/jas.v7n8p8I

Umaña, G. P. (2019). Mariposas ticas traspasan las fronteras. Universidad de Costa Rica. https://www.ucr.ac.cr/noti cias/2019/03/20/mariposas-ticas-traspasan-las-fronteras.html

Veltman, K. (2009). How can zoos import and display butterflies for educational purposes in a sustainable way? International Zoo Yearbook, 43(I), I24-130. https://doi.org/10.IIII/j.1748-1090.2008.00069.x

Virapongse, A., Schmink, M., \& Larkin, S. (20I4). Value chain dynamics of an emerging palm fiber handicraft market in Maranhão, Brazil. Forests, Trees and Liveliboods, 23(I-2), 36-53. https://doi.org/10.1080/I4728028.20I 3.868707

Viso, A. M. (2005). Sostenibilidad y gobernanza. Arbor: Ciencia, Pensamiento y Cultura, I8I(715), 317-331. https://do i.org/10.3989/arbor.2005.i715.415

Wong, F. K., \& Fung, T. (2015). Ecotourism planning in Lantau Island using multiple criteria decision analysis with geographic information system. Environment and Planning B: Planning and Design, 43(4), 640-662. https:/ /doi.org/10.1177/0265813515618583

\section{Notes}

* Research article

CC BY 